\title{
EXTRACTION AND EVALUATION OF ISAPGHULA SEED POLYMER AS PHARMACEUTICAL EXCIPIENT
}

\author{
Nagar Praveen Kumar *, Parvez Nayyar, Sharma Pramod Kumar \\ Department of Pharmacy, School of Medical and Allied Sciences, Galgotias University, Yamuna Expressway, Greater \\ Noida, Gautam Buddh Nagar, India
}

\begin{abstract}
:
Aim of study. Present study includes extraction and characterization the isapghula (Plantago Ovata) seed polymer as pharmaceutical excipients.

Material and methods: By using water based extraction by heating mental isapghula seed polymer was obtained. For characterization of the extracted isapghula seed polymer phyto chemical screening was done and micromeritic properties, flow behavior, Solid forming capacity of polymer was also evaluated.

Results: The result predicts that extracted isapghula seed polymer was soluble in warm water while insoluble in cold water and in organic solvents. It was also exhibited that extracted isapghula seed polymer had good flow properties. $\mathrm{pH}$ was found 7.3 , this showed that can be used in dosage form without any irritation. Results also showed that this polymer can be used to tablets binder.

Conclusions: From the results it was concluded that evaluated parameters showed that isapghula derived seed polymer can be used as pharmaceutical excipient to prepare solid as well as semisolid dosage form.

Key words: Isapghula seed polymer, extraction, characterization, natural polymer, pharmaceutical excipients.
\end{abstract}

\section{INTRODUCTION:}

Various natural gums come under the category of polysaccharide such as tragacanth, karaya, acacia and khaya. Natural gums have been wildly used as tablet binders, emulgents and thickeners in cosmetics and suspensions as film-forming agents and transitional colloids. Generally most of the gums absorb water, causes the gum to swell and exude by the incision. Almost gums composed of salts such as calcium, magnesium and potassium salts of bassoric acid, known as bassorin. Some of the gums have been reportedly used in an insoluble powder for suspending as a suspending agent, an emulsifying agent in emulsions for oils, resin and a binding agent ${ }^{1}$.

Isapghula seed polysaccharide (ISP) is a natural polymer which is derived from the isapghula seed. The main component of isapghula seed has been identified as a non-ionic, neutral; the configuration of ISP gives the product a 'mucin-like' molecular structure, thus conferring optimal superdisintegrant properties. Research has also shown that, at the concentrations present in the polysaccharide formulations studied, one important characteristic of ISP that makes it similar to natural ${ }^{2}$.

\section{MATERIAL AND METHODS}

\section{Extraction Procedure:}

Isapghula consists of dried seeds of the plant plantago ovata and it contains mucilage which is present in the epidermis of the seeds. The seeds of Plantago ovata were soaked in distilled water for $48 \mathrm{hrs}$. Then boiled for few minutes for complete release of mucilage into water.
The material was squeezed through muslin cloth for filtering and separating out the marc. Then, an equal volume of acetone was added to the filtrate so as to precipitate the mucilage. The separated mucilage was dried in oven at temperature less than $60^{\circ} \mathrm{C}$. The mucilage of plantago ovata has better super disintegration property than Crosspovidone ${ }^{3-5}$.

\section{Physicochemical Characterization of Isapghula Seed Polymer}

Identification tests for carbohydrates: As the authors described in previous publication, Extracted gum was mixed with Molish's reagent followed by addition of sulfuric acid. The violet color ring appeared at junction of mixture in test tube that confirms the presence of carbohydrates ${ }^{6-7}$.

Determination of purity of isapghula seed polymer: For determine purity of extracted isapghula polymer tests for alkaloids, proteins, mucilage, fats, tannins and amino acids were performed as already described by authors in previous publication ${ }^{6-7}$.

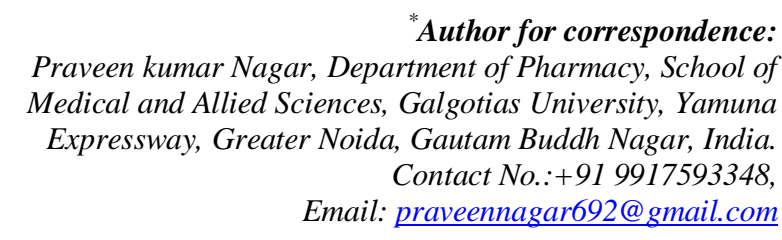


Organoleptic evaluation of isolated isapghula seed polymer: As authors described elsewhere, isolated isapghula seed polymer was characterized for organoleptic properties such as color, odor, taste, touch, fracture and texture ${ }^{6}$.

Solubility behavior: As already described by author's one part of dry isapghula seed polymer powder was shaken with different solvents and their solubility was determined ${ }^{6}$.

pH of isapghula seed polymer: Firstly, extracted isapghula seed polymer was weighed and then dissolved in water separately to get a $1 \% \mathrm{w} / \mathrm{v}$ solution. The $\mathrm{pH}$ of solution was determined using digital $\mathrm{pH}$ meter as described by authors in previous publication ${ }^{6}$.

Bulk density and bulkiness: It has been described by authors that inverse of bulk density is called as bulkiness. As per previous study accurately weighed quantity of (50 g) was introduced into a graduated measuring cylinder. The cylinder was fixed on the bulk density apparatus and the volume occupied by the powder was noted. Then, the powder was subjected to tapping in a bulk density apparatus until constant volume was obtained. The final volume (bulk volume) was noted ${ }^{6,8-9}$.

True density: Among various methods available for the determination of true density, liquid displacement method is the simplest method and was used in the present study. Acetone was selected as the liquid for displacement because isapghula polymer is insoluble and heavy in acetone. This method has been used by authors 6, 8-9

Powder flow property: Flow characteristics were measured by angle of repose as previous publication of authors. Same study was repeated here. Using the readings and the formula, the angle of repose was calculated $^{6,8-9}$.

Powder Compressibility (Carr's Consolidation Index): This property is also known as compressibility. As described in previous publication finely powdered isapghula seed polymer (5 g) was transferred into a measuring cylinder and calculations were done using bulk density apparatus ${ }^{6,8-9}$.

\section{RESULTS AND DISCUSSION}

It has been observed that isolated isapghula seed polymer is creamish brown in color, had no odor and taste. $\mathrm{pH}$ of $1 \%$ solution was found to be 7.3 , which indicated that it should be non-irritating for mucous membrane. Solubility study showed that it was sparingly soluble in cold water, quickly soluble and form viscous colloidal solution in warm water where as insoluble in ethanol, acetone, benzene, ether and methanol. The isolated sample was subjected to identification. This showed presence of carbohydrates in sample powder. Confirmation of isapghula polysaccharide was done when it gave negative test for mucilages, gums, tannins, alkaloids and proteins. Other phyto-constituents were absent in the isolated powder. This can be considered as proof for purity of the isolated isapghula seed polysaccharide as depicted in table 1

Table1. Determination of purity of isolated isapghula seed polysaccharide

\begin{tabular}{|l|c|}
\hline Tests & Present/Absent \\
\hline Carbohydrates & + \\
\hline Hexose Sugar & + \\
\hline Monosaccharides & - \\
\hline Proteins & - \\
\hline Fats and oils & - \\
\hline Tannins and Phenolic Compounds & - \\
\hline Alkaloides & - \\
\hline Amino acids & - \\
\hline Mucilage + Present; - Absent & - \\
\hline Gums & - \\
\hline
\end{tabular}

Physical characterization of isapghula seed polymer was carried out for angle of repose, Carr's index, true density, bulk density and bulkiness for powder flow behavior where as these properties depends on the particle size, particle size distribution their shape. Angle of repose of isapghula seed polymer $32.2^{\circ}$, it indicates that powder is passable flowing. Carr's index values of isapghula seed polymer is $14.12 \%$, its show good flow properties. Hausner,s ratio value 1.16 show good flow. Tapped density value of isapghula seed polymer is $0.82 \mathrm{gm} / \mathrm{ml}$ .Bulk density value $0.70 \mathrm{gm} / \mathrm{ml}$. Bulkiness value of isapghula seed polymer is 1.41 . Which indicate desirable flow characteristics.

Table 2: Micromeritic study data of isapghula polymer ${ }^{\#}$

\begin{tabular}{|c|c|}
\hline Parameters & Values \\
\hline Angle of repose $\left({ }^{\circ}\right)$ & $32.2 \pm .818$ \\
\hline Carr's index & $14.12 \pm 0.85$ \\
\hline Tapped density $(\mathrm{gm} / \mathrm{ml})$ & $0.82 \pm 0.06$ \\
\hline Bulk density $(\mathrm{gm} / \mathrm{ml})$ & $0.70 \pm 0.045$ \\
\hline Bulkiness & $1.41 \pm 0.090$ \\
\hline Hausner ratio & $1.16 \pm 0.01$ \\
\hline
\end{tabular}

Result in table 2 predicts that isapghula seed polymer has passable flow so that ISP can be used as a pharmaceutical excipient.

\section{CONCLUSION:}

It can be concluded from the whole study that isapghula seed derived polymer can be used as a pharmaceutical excipient for oral drug delivery. It has $\mathrm{pH}$ value of 7.3, so nonirritant in nature. So this polymer has sufficient potential to be use as pharmaceutical excipients.

\section{ACKNOWLEDGEMENT:}

Authors are highly thankful to the Department of Pharmacy, School of Medical Allied Sciences, Galgotias University, Greater Noida India for providing library facility during literature survey.

Conflict of interest: Authors have no conflict of interest. 


\section{REFERENCES:}

1. Malviya R., Srivastava P, Upendra K, Bhargava CS, Sharma PK, Formulation and comparison of suspending properties of different natural polymers using paracetamol suspension, IJDDR, 2010, 2, 886-891.

2. Sahoo S, Sahoo R, Nayak L, Padma, Isapghula Seed Polysachharide: A versatile biopolymer for mucoadhesive applications, JPBMS, 2011, 8, 1-12.

3. Jyothi G, Lakshmi PK, Comparative evaluation of natural and synthetic superdisintegrants with newer superdisintegrant Kyron T-314, Acta Pharmaceutica Sciencia, 2011, 35-44.

4. Deveswaran R, Bharath S, Furtado S, Basavaraj BV, Abraham S, MadhavanV, Studies on the Disintegrant properties of Mucilage and Seed Powder of Plantago ovate, Int. J. of Chem. Tech. Res, 2009, 1, 621-626.

5. Shirsand S, Suresh S, Para M, Swamy P, Kumar DN, Plantago ovata mucilage in the design of fast disintegrating tablets, Indian Journal of Phrmaceutical Science, 2009, 71, 41-45.

6. Malviya R, Extraction and characterization of selected mucilage as pharmaceutical excipients, Polim. Med, 2011, 3, 39-44.

7. Lala, PK. Practical Pharmacognosy. Calcutta: Lina Guha. p. 135.

8. Malviya R, Srivastava P, Bansal M, Sharma P K, Preparation and Evaluation of Disintegrating Properties of Cucurbita maxima Pulp Powder, International Journal of Pharmaceutical Sciences, 2010, 2, 395-399.

9. Malviya R., Shukla P, Srivastava P, Preparation Characterization and Evaluation of Chitosan-Gum Arabic Coacervates as Excipient in Fast Disintegrating/ Dissolving Drug Delivery system, FABAD Journal of Pharmaceutical Sciences, 2009, 34, 213-223. 